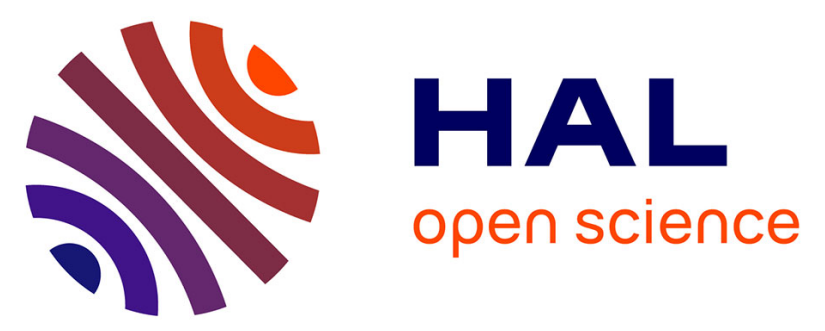

\title{
Plasma HDL-cholesterol and triglycerides, but not LDL-cholesterol, are associated with insulin secretion in non-diabetic subjects
}

Andrea Natali, Simona Baldi, Fabrice Bonnet, John Petrie, Silvia Trifiro, Domenico Trico, Andrea Mari

\section{To cite this version:}

Andrea Natali, Simona Baldi, Fabrice Bonnet, John Petrie, Silvia Trifiro, et al.. Plasma HDLcholesterol and triglycerides, but not LDL-cholesterol, are associated with insulin secretion in nondiabetic subjects. Metabolism, 2017, 69, pp.33-42. 10.1016/j.metabol.2017.01.001 . hal-01921752

HAL Id: hal-01921752

https://hal-univ-rennes1.archives-ouvertes.fr/hal-01921752

Submitted on 14 Nov 2018

HAL is a multi-disciplinary open access archive for the deposit and dissemination of scientific research documents, whether they are published or not. The documents may come from teaching and research institutions in France or abroad, or from public or private research centers.
L'archive ouverte pluridisciplinaire HAL, est destinée au dépôt et à la diffusion de documents scientifiques de niveau recherche, publiés ou non, émanant des établissements d'enseignement et de recherche français ou étrangers, des laboratoires publics ou privés. 


\section{Plasma HDL-cholesterol and triglycerides, but not LDL-}

\section{cholesterol, are associated with insulin secretion in non diabetic}

\section{subjects}

Andrea Natali ${ }^{1}$, Simona Baldi ${ }^{1}$, Fabrice Bonnet ${ }^{2}$, John Petrie $^{3}$, Silvia Trifirò ${ }^{1}$, Domenico Tricò ${ }^{1}$, Andrea Mari ${ }^{4}$, on behalf of the RISC Investigators.

\footnotetext{
Rennes 1, Rennes, France Centre, University of Glasgow, Glasgow, UK

${ }^{4}$ CNR Institute of Neuroscience, Padova, Italy

\section{Corresponding author:}

Andrea Natali

Department of Clinical and Experimental Medicine

Via Roma, 67

56100 Pisa, Italy

Phone: +39050992814

Fax: +39050 553235

E-mail: andrea.natali@med.unipi.it
}

${ }^{1}$ Department of Clinical and Experimental Medicine, University of Pisa, Italy

${ }^{2}$ Service Endocrinologie-Diabétologie, Centre Hospitalo-Universitaire (CHU), University

${ }^{3}$ Institute of Cardiovascular and Medical Sciences BHF Glasgow Cardiovascular Research

Short title: Plasma lipids and insulin secretion

Key words: insulin secretion in vivo, lipoproteins, triglycerides, HDL-cholesterol, $\beta$-cell function

List of abbreviations BcGS: beta cell glucose sensitivity; BMI: body mass index; FFM: fat free mass; ISR@ 5: insulin secretion rate at $5.0 \mathrm{mmol} / \mathrm{l}$ of plasma glucose; ISR fast: fasting insulin secretion rate; IC fast: insulin clearance fasting; IC ogtt: insulin clearance during OGTT; ISR ogtt: total OGTT insulin secretion; NEFA: non esterified fatty acids; OGTT: oral glucose tolerance test; PFR: potentiation factor ratio, RS: rate sensitivity 


\section{Abstract}

Objective - Experimental data support the notion that lipoproteins might directly affect beta cell function, however clinical data are sparse and inconsistent. We aimed at verifying whether, independently of major confounders, serum lipids are associated with alterations in insulin secretion or clearance non diabetic subjects.

Methods - Cross sectional and observational prospective (3.5 yrs), multicentre study in which 1,016 non diabetic volunteers aged 30-60 yrs and with a wide range of BMI (20.0$39.9 \mathrm{~kg} / \mathrm{m}^{2}$ ) were recruited in a setting of University hospital ambulatory care (RISC study). Main outcome measures: baseline fasting lipids, fasting and OGTT-induced insulin secretion and clearance (measured by glucose and C-peptide modelling), peripheral insulin sensitivity (by the euglycemic clamp). Lipids and OGTT were repeated in 980 subjects after 3.5 years. Results - LDL-cholesterol did not show independent associations with fasting or stimulated insulin secretion or clearance. After accounting for potential confounders, HDL-cholesterol displayed negative and triglycerides positive independent associations with fasting and OGTT insulin secretion; neither with insulin clearance. Low HDL-cholesterol and high triglycerides were associated with an increase in glucose-dependent and a decrease in non glucose-dependent insulin secretion. Over 3.5 years both an HDL- cholesterol decline and a triglycerides rise were associated with an increase in fasting insulin secretion independent of changes in body weight or plasma glucose.

Conclusions - LDL-cholesterol does not seem to influence any major determinant of insulin bioavailability while low HDL- cholesterol and high triglycerides might contribute to sustain the abnormalities in insulin secretion that characterise the pre diabetic state. 


\section{Introduction}

Plasma insulin levels, both in the fasting and stimulated conditions, display al large inter individual variability, which is only in part explained by insulin sensitivity, plasma glucose and the degree of obesity $[1,2]$. Recently, evidence has accrued to suggests that serum lipids might directly modulate $\beta$-cell function [3] and insulin clearance [4]. Incubation of mouse $\beta$-cells and rat islets with human HDL particles, or their major apolipoproteins A-I and A-II, directly enhances glucose-stimulated insulin secretion [5] and also prevents the adverse effects of oxidised LDL particles on $\beta$-cells [6]. In subjects with type 2 diabetes however, rising ApoA-I by $240 \%$ through an i.v. infusion of reconstituted HDL, elicited only a minor (10\%) improvement in insulin secretion [7] and in the ILLUMINATE trial [8] the sustained HDL-cholesterol increase (HDL-C: $+0.76 \mathrm{mmol} / \mathrm{l}$ ) produced by torcetrapib was associated with only a minor improvement of the metabolic control, which was evident only because in those on atorvastatin treatment it slightly worsened during the trial. Furthermore, no clear association has been found between serum lipids-related genetic variants (SNPs) and indices of insulin secretion, rather a negative association with high HDL-C related SNPs was observed when the genetic variants were selected for being exclusively effective on HDL-C and not on the other lipids [9].

The only one study exploring the effect of triglycerides on B-cell in vitro has demonstrated a down regulation of glucose-induced insulin secretion and accelerated apoptosis [10]. In contrast, the infusion of a lipid emulsion in anesthetised rats produced a 3fold increase in insulin secretion through a 33 -adreno receptor mediated increase in islet blood flow[11]. Data on triglycerides in humans are limited because most studies have focused on non-esterified fatty acids (NEFA) or failed to control for insulin sensitivity. Several in vitro and in vivo experimental studies evaluating the effect of acute exposure to NEFA - not triglycerides - have consistently reported a negative impact on insulin secretion 
[12-15]. In healthy humans, however we could not find any relationship between endogenous circulating NEFA and glucose-induced insulin secretion, independent from potential confounding factors [16]. Moreover, a prolonged (48h) lipid infusion, doubling NEFA levels and only marginally affecting serum triglycerides, reduced both glucoseinduced insulin secretion and insulin clearance, but only in subjects at risk of diabetes (obese and $1^{\text {st }}$ degree offspring) while it stimulated insulin secretion in control subjects $[17,18]$. In healthy humans [19] the ingestion of fat load acutely produced a doubling of i.v. glucosestimulated insulin secretion and a 50\% reduction in insulin clearance, which was associated to a marked reduction in insulin sensitivity making it difficult to ascertain the direct effect of triglycerides per se. Similarly, large epidemiologic study have observed that high triglycerides and low HDL-C [20] - and also fatty liver [21] - are associated with a reduction in insulin clearance, but again to what extent this is related to the presence of insulin resistance remains unclear.

Recently LDL-Cholesterol (LDL-C) has also been shown to modulate directly insulin secretion. In experimental animal models, elevated serum total and LDL-C levels produced an increase of the $\beta$-cell cholesterol pool, which, by interfering with the translocation of glucokinase, down regulated glucose-induced insulin secretion [22]. On the other hand, in clinical trials chronic cholesterol lowering with statins has been associated with an increased incidence of diabetes [23] and a recent analysis of the METSIM cohort suggests that statin use might produce an impairment in insulin secretion [24].

In summary, the evidence in favour of a role of each major serum lipid substrate in directly modulating insulin secretion or clearance, though still weak and fragmented, is emerging. Possible explanations for the inconsistencies are the lack of accurate insulin secretion and insulin sensitivity measurement, the interference of pharmacologic treatments and, with regard to triglycerides, the lack of a clear distinction between the effects of NEFA 
and lipoproteins. We designed this study to explore, in the physiologic domain, the impact of circulating lipid levels on insulin secretion in a large cohort of healthy individuals in whom insulin sensitivity was accurately measured by means of the euglycemic hyperinsulinemic clamp technique and insulin secretion extensively assessed by OGTT C-peptide/glucose modelling. Follow-up data were used to test the hypothesis eventually generated by the cross sectional analysis.

\section{Subjects and Methods}

\subsection{Study participants}

RISC (Relationship between Insulin Sensitivity and Cardiovascular risk) is a multicentre, prospective, observational European cohort study whose rationale and methodology have previously been described in detail [25]. In brief, participants were enrolled at 19 clinical centres in 14 European countries, according to the following inclusion criteria: either sex, age 30-60 years (balanced 10-year strata), and clinically healthy allowing for obesity up to class II (i.e. BMI $<40 \quad \mathrm{~kg} / \mathrm{m}^{2}$ ) as defined by the WHO (http://apps.who.int/bmi/index.jsp). Exclusion criteria were: treatment for any chronic disease, pregnancy, any cardiovascular disease or previous event, cancer (in the last 5 years), renal or liver failure, arterial blood pressure $\geq 140 / 90 \mathrm{mmHg}$, fasting plasma glucose $\geq 7.0$ mmol/l, 2-hour plasma glucose (on OGTT) $\geq 11.0 \mathrm{mmol} / \mathrm{l}$, total serum cholesterol $\geq 7.8$ $\mathrm{mmol} / \mathrm{l}$, serum triglycerides $\geq 4.0 \mathrm{mmol} / \mathrm{l}$, or ECG abnormalities. Of the initial cohort of 1,320 subjects who underwent OGTT and the euglycemic insulin clamp for measurement of insulin secretion and sensitivity at baseline, serum lipids and major apolipoproteins at baseline were measured in a sub-group of 1,077 selected to have also the 3.5 years follow-up data. Sixty one subjects were excluded for problems in the baseline lipids and/or apoliporoteins determinations (missing values, outliers, poor assay quality control, internal inconsistencies) therefore the present analysis is based on the baseline data of 1,016 subjects 
who had a complete and validated baseline data set and on 980 subjects in whom lipids, apolipoproteins and insulin secretion data were available also at the 3.5 years follow-up. Local Ethics Committee approval was obtained by each recruiting centre.

\subsection{Euglycemic insulin clamp}

Exogenous insulin was administered intravenously as a primed-continuous infusion at a rate of $240 \mathrm{pmol} \min ^{-1} \mathrm{~m}^{-2}$ simultaneously plasma glucose level were maintained within 4.5$5.5 \mathrm{mM}$ by means of a variable $20 \%$ dextrose/water infusion on the bases of bed side plasma glucose determination. Blood samples were obtained every 20 min for plasma insulin and cpeptide determination. Insulin sensitivity (M/I, in units of $\mu \mathrm{mol} \min ^{-1} \mathrm{~kg}_{\mathrm{FFM}}{ }^{-1} \mathrm{pM}^{-1}$ ) was expressed as the ratio of the glucose infusion rate (M value), averaged over the final $40 \mathrm{~min}$ of the 2-hour clamp and normalized by the fat-free mass (FFM), measured by bioimpedance (TB300, TANITA, Tokyo, Japan), to the mean achieved plasma insulin concentration.

\subsection{Analytical methods}

Blood was separated into plasma and serum aliquots and stored at $-80{ }^{\circ} \mathrm{C}$ for centralized analytes determination. Serum total cholesterol, HDL-C, LDL-C and triglycerides were measured by enzymatic colorimetric test (Roche Modular systems), NEFA by an immunoenzymatic assay (Randox), plasma insulin and C-peptide by a two-sited, timeresolved fluoroimmunoassay (AutoDELFIA Insulin kit, Wallac Oy, Turku, Finland). The glucagon assay (developed in J. Holst's laboratory in Copenhagen, Denmark) is highly specific for the free $\mathrm{C}$ terminus of the molecule, and therefore specific for pancreatic glucagon. Serum apolipoproteins AI, AII, B100, CIII, and E were assayed with Milliplex® APO-62K kits on a Bio-Plex 200 System instrument (Bio-rad Laboratories).

\subsection{Beta cell function modeling}

All the parameters of $\beta$-cell function were generated by using the OGTT C-peptide and glucose data. The model used to reconstruct insulin secretion and its control by glucose has 
previously been described [26]. In brief, the analysis consists in three blocks: a) a model for smoothing and interpolating plasma glucose profile based on glucose concentration determinations; b) a model for describing the dependence of insulin (or C-peptide) secretion on glucose concentration; and c) a model of C-peptide kinetics individually adjusted to the subject's anthropometric data according to Van Cauter et al. [27]. With regard to the relationship between insulin release and plasma glucose concentrations (block b), it is modeled as the sum of two components. The first component represents the dependence of insulin secretion on absolute glucose concentration at any time point, and is characterized by a quasi linear dose-response function whose slope in the observed glucose range, is defined ß-cell glucose sensitivity (BcGS). This parameter can be modulated by several factors (i.e., non-glucose substrates, gastrointestinal hormones and neurotransmitters), which are collectively modelled as a potentiation factor whose value is set to be a positive function of time, and to average one during the experiment. The ratio of the values at 100-120 min vs 0$20 \mathrm{~min}$ (potentiation factor ratio, PFR) is used to express with a single parameter this time dependent function. The second insulin secretion component represents a dynamic dependence of insulin secretion on the rate of change of glucose concentration. This component is known as the derivative component, and is determined by a single parameter, denoted as rate sensitivity (RS). Insulin secretion rate at $5 \mathrm{mM}$ glucose (ISR@5) is calculated from the $\square$-cell dose-response, corrected for the potentiation factor at time 0 (basal), and represents insulin secretion in basal conditions if basal glucose were $5 \mathrm{mM}$ in each subject. Fasting insulin secretion (ISR fast, pmol $\min ^{-1} \mathrm{~m}^{-2}$ ) is the value of insulin secretion measured at time 0 while total OGTT insulin secretion (ISR ogtt, $\mathrm{nmol} \mathrm{m}$ ) is the integral of insulin secretion during the entire $2 \mathrm{~h}$ OGTT. Insulin clearance was calculated as the ratio of mean ISR to the mean insulin concentration both in the fasting state (IC fast) and during the OGTT (IC ogtt). 


\subsection{Statistical analysis}

Data are reported as mean \pm SD or as least square mean \pm SEM. Differences between means and prevalence rates have been evaluated with ANOVA and chi-squared, respectively. The associations between lipids and insulin related variables were described using quartiles in order to appreciate the shape of the relationship (linear vs non linear). Since most lipid variables were different in women and men for all analyses we used sex specific quartiles. Two-way ANOVA was used for quartiles mean comparisons and ANCOVA when testing differences in means adjusted for covariates. General linear models (standard least square) were used to test the simultaneous dependence of continuous variables on single or multiple parameters. Since most lipid variables displayed a non normal distribution we used Spearman's $\rho$ in univariate analyses and the log-transformed variable in multivariate analysis. To allow a direct comparison between variables independently of their units and their biologic range, the estimated multivariate regression coefficients were expressed as standardized coefficients $(S T D \beta)$. Variance inflation factor (VIF) was calculated for each independent variable, which was eventually dropped from the model if the VIF value was $\geq 3$. A two-tailed $p$ value of $\leq 0.05$ was considered statistically significant. For the follow-up data the subjects were divided in quartiles on the bases of the $3.5 \mathrm{yrs}$ change in plasma HDL-c and triglycerides. For each quartile we then calculated the mean values of change in fasting insulin as a simple mean and adjusted for the changes in BMI and in fasting glucose using and ANCOVA model. All analyses were run on JMP® 9.0.1.

\section{Results}

The metabolic and anthropometric characteristics of the study population are shown in Table 1. Women, on average, showed overall a healthier metabolic profile with respect to men, which was coupled to a lower prevalence of overweight $(30 v s 50 \%, \mathrm{p}<0.01)$. The single components of the lipid profile and the insulin values displayed a wide variability 
covering almost their entire physiologic domain. The mean values and the distributions of LDL-C and HDL-C and that of triglycerides were different in women and men; therefore gender specific quartiles were used to maintain a balanced gender representation within each quartile.

3.1 Cross-sectional data: plasma insulin, insulin secretion and clearance - In the whole population, both fasting and OGTT plasma insulin values displayed a direct quasi-linear relationship with both serum LDL-C and triglycerides quartiles and an inverse relationship with HDL-C (Figure 1). After adjusting the mean insulin values for gender, age, BMI and insulin sensitivity $(\mathrm{M} / \mathrm{I})$, the association, though partially attenuated, was still evident for both HDL-C and triglycerides but was completely lost for LDL-C (Figure 1). In univariate analysis on continuous variables, including all the available lipid and apolipoprotein parameters, serum HDL-C and triglycerides showed the strongest associations with the two major determinants of plasma insulin concentration i.e. insulin secretion and insulin clearance (Table 2). Also ApoB, ApoE, ApoCIII and LDL-C showed a tendency to cosegregate mainly with insulin secretion, however all the associations were weaker and no longer significant after adjusting for serum triglycerides. The correlations between HDL-C and triglycerides with insulin clearance, both fasting and during the OGTT, lost statistical significance when adjusted for gender, age, BMI and insulin sensitivity; in contrast, all the associations with insulin secretion, both fasting and OGTT, though partially attenuated, were still present and unaltered by further adjusting for the cognate components of the lipid profile with a quasi-linear and additive effect of both HDL-C and triglycerides (Figure 2). In multivariate analysis, HDL-C and triglycerides were both correlated with fasting and OGTT insulin secretion also after taking into account all other relevant covariates including age, gender, waist, BMI, insulin sensitivity and, interestingly, also the prevailing plasma glucose values (Table 3). Neither gender nor BMI displayed significant interactions with lipids and 
the analysis repeated separately on males and females yielded similar standardized $\beta$ coefficients (supplemental material table). In quantitative terms the correlations of triglycerides appeared stronger than HDL-C displaying two-fold higher standardized $B$ coefficients values that, for fasting insulin secretion, were similar to those of BMI, insulin sensitivity and plasma glucose. None of the apolipoproteins entered into the model nor significantly modified the lipids standardized $\beta$ coefficients.

3.2 Cross sectional data: $\beta$-cell function parameters - The mechanisms by which HDL$\mathrm{C}$ and triglycerides, with opposite effects, modulate insulin secretion were evaluated by analysing the correlations between the two serum lipids and the four major components that characterise $B$-cell function as estimated from the modelling of plasma C-peptide and glucose. Neither lipid variable correlated with BcGS or with RS. HDL-C was strongly associated with both ISR@5.0 and PFR (rho=-0.175 and 0.139 respectively, $\mathrm{p}<0.0001$ for both), whilst triglycerides showed opposite associations with these two components (rho $=0.110$ and $r h o=-0.080, p<0.0005$ and $p<0.01$, respectively); in Figure 3 the shape of the relationship between the variables can be appreciated and the association with HDL-C appears quasi-linear and steeper. In addition, in the whole data set HDL-C, but not triglycerides, was inversely correlated with fasting plasma glucagon $(\mathrm{rho}=-0.20)$.

3.3 Follow-up data - The hypothesis that serum lipids modulate insulin secretion was tested on prospective data. At the 3.5 year follow-up, changes in serum HDL-C and in triglycerides were associated with the expected changes in fasting insulin secretion although with a non symmetric pattern such that the deterioration of each serum lipid (a decrease in HDL-C and an increase in triglycerides) was effective while the opposite change was not; this pattern remained evident also after taking into account the concomitant 3.5 years changes in BMI and in fasting plasma glucose (Figure 4). 


\section{Discussion}

The major findings of this study are: a) neither total nor serum LDL-C is associated with insulin secretion or insulin clearance; b) low HDL-C and high triglycerides are associated with increased insulin secretion in an additive manner, independently of plasma glucose, peripheral insulin resistance or obesity; c) HDL-C produces a downward shift of the B-cell glucose-insulin dose-response curve (acting on IS@5.0 and leaving unaltered BcGS) and stimulates potentiation while triglycerides exert opposite effects; d) a mild increase in serum triglycerides or a small decrease in HDL-C over time up regulates fasting insulin secretion independently of the concomitant changes in weight or in fasting glucose. These effects do not appear to be mediated by any single major apolipoprotein.

Although circulating levels of LDL-C, within the physiologic domain, do not seem play a role in modulating insulin secretion, we cannot exclude that more extreme level or acute manipulations might be effective. In isolated cells, islets, and experimental animals the enrichment of $ß$-cell intracellular cholesterol through genetic knock-out of the apo E [22] or ABCA1 [28] genes causes an inhibition of glucose-induced insulin secretion that is removed when $ß$-cell are pharmacologically [22] or genetically [29] depleted of cholesterol. In subjects with familial hypercholesterolemia - and a defective LDL receptor - the prevalence of diabetes is on average approximately half than in the non-affected relatives and is inversely proportional to the severity of the disease [30] suggesting a negative effect of cholesterol in the $\beta$-cell. On the other hand, the results of clinical studies show that chronic treatment with statins has either a mild negative [24] or no effect on glucose-induced insulin secretion [31, 32] and a recent analysis adopting a Mendelian randomization approach, reported a lack of association between high serum LDL-C related SNPs and insulin secretion [9]. Presumably in vivo in normal subjects neither the circulating LDL-C levels nor the treatment with statin affects the intracellular LDL pool of the $\beta$-cell to an extent similar to 
that achieved in experimental studies and in familial hypercholesterolemia. We cannot exclude that statins, which might also impact directly on insulin secretion through other intracellular pathways [33], in certain conditions could exert a relevant influence on $\beta$-cell function.

Our data show that the association of HDL-C and triglycerides with fasting and glucose stimulated insulin secretion is physiologically relevant; each lipid substrate showing a strength similar to other variables recognised as important in the modulation of B-cell function such as glucose, obesity and peripheral insulin sensitivity. In addition, if we take into account that the two lipids in the population tend to be inversely associated their combined influence will be even more relevant and could justify, to some extent, the increase in insulin secretion and the reduction of potentiation (i.e. non glucose-mediated insulin secretion) that characterize the pre diabetic state independently of peripheral insulin resistance [34]

With regard to HDL-C our findings are in contrast with experimental studies where the exposure of B-cells to either ApoAI or discoidal HDL resulted in an enhanced basal and glucose-stimulated insulin secretion [5, 6, 29]. Moreover, the few available clinical studies are also not consistent with our data, however in one study the effect on insulin secretion was small (approx. 10\%) - with respect to the $240 \%$ increase in ApoAI - and was based on a method (HOMAß), which was not designed for non steady-state experimental conditions [7]. In another study in 10 non-diabetic subjects treated for 14 days with a CETP inhibitor, postprandial insulin was increased; however, the latter was measured only at a single time point (15 min after a standardized meal), the difference was not coupled to an increase in the plasma c-peptide and fasting insulin did not change [35]. The extreme manipulations characteristic of the in vitro studies, probably affecting the intracellular lipid concentrations, and the heterogeneity - and low accuracy - of the methodological approaches used for the 
evaluation of $\beta$-cell function of the clinical studies might explain the discrepancies with our results. Noteworthy, in a post hoc analysis of the ILLUMINATE trial [8] it was reported that the $+0.8 \mathrm{mmol} / \mathrm{l} \mathrm{HDL}-\mathrm{C}$ rise produced by torcetrapib was associated with a significant reduction of plasma fasting insulin in the absence of relevant changes in fasting plasma glucose concentration both in the diabetic $(n=6,661)$ and in the non diabetic $(n=8,406)$ cohort. This is in full agreement with our data, which would predict a $17 \mathrm{pmol} / \mathrm{l}$ downward shift of the glucose-insulin dose-response curve that is close to the effect observed in non diabetic cohort $(-25 \mathrm{pmol} / \mathrm{l})$. Finally, very recently insulin secretion was found to be dramatically increased a small group of subjects with loss-of-function mutations of ABCA1 resulting in extremely low circulating levels of HDL-C [36] and genetic variants specific for low serum HDL-C are associated with increased insulin secretion as assessed through the OGTT derived disposition index [9].

With regard to triglycerides it seems unlikely that FFA explain the observed associations since in our database circulating NEFA had no correlation with circulating triglycerides (Rho: 0.03) and were not correlated with insulin secretion in multivariate models accounting for BMI and insulin sensibility. We cannot exclude that elevated triglycerides are associated with a plasma NEFA composition enriched in long chain NEFA, which have been shown to stimulate insulin secretion [37].

While we acknowledge that our data are mainly cross sectional, they are consistent with the notion that dyslipidaemia might represent an extra stimulus on the $\beta$-cell in addition to that caused by glucose, whole body insulin resistance and obesity. Noteworthy, the $15-20 \%$ upward shift in ISR@5 (and the whole glucose-insulin dose-response curve), provided independently by either low HDL-C or high triglycerides $\left(1^{\text {st }} v s 4^{\text {th }}\right.$ quartile $)$ translates into a $15-20 \%$ increase in total daily insulin requirement for each trait and a 30-40\% increase for the combination of the two, (as it occurs in subjects with metabolic syndrome). Conversely, 
the treatment of the dyslipidemia by unloading the $\beta$-cell and restoring potentiation might help in preventing the progression to diabetes. Our follow up data confirm this possibility although they reveal an asymmetric relationship between the changes in lipids and insulin secretion (Figure 4). The asymmetric shape of the dose-response curve could be a type 2 error caused by error of the primary measurements (changes) and their size (small). However, indirect support for our hypothesis is provided by the finding that low HDL and high triglycerides independently predict the development to diabetes in normal subjects [38] and that treatment with bezafibrate was associated with a lower incidence of diabetes in a small study in IFG subjects [39] and with a slower decline of HOMAß over the 2 years of follow up in the diabetic cohort of the BIP trial [40]. Finally we acknowledge that a mechanism through which the dyslipidemia might increase insulin secretion without modifying the slope of the glucose-insulin dose-response curve is by promoting endogenous glucose production either directly, by providing an excess of substrates (triglycerides), or indirectly, by stimulating glucagon secretion (HDL-C) as suggested by the observed correlation. With regard to the effect on potentiation we can only speculate that it could involve incretins secretion on the bases of recent evidence that in $\mathrm{db} / \mathrm{db}$ mice the treatment with bezafibrate improves GLP-1 sensitivity while reducing triglycerides by $50 \%$ and rising HDL by $20 \%$ [41]. Only a clinical trial designed to evaluate the effect of fibrates on hepatic insulin sensitivity, glucagon and potentiation is necessary to confirm our hypotheses on the mechanisms.

\section{Strengths/weakness}

Strengths of this study are: the large sample size, the peculiarity of the population (without relevant comorbidities or drug treatments), the standardized procedures, the centralized laboratory assessments and the accurate and simultaneous assessment of both insulin sensitivity and insulin secretion. The weakness are inherent to the fact that neither 
regression nor correlation analysis allow the definition of causality. This objection clearly is not relevant for LDL-C, for which we did not find associations with insulin secretion; neither it is relevant for the effects of HDL-C and triglycerides on the partial loss of potentiation, whose impact on lipid metabolism appears unlikely on physiopathology grounds. Certainly we neither can exclude that it is hyperinsulinemia that modulates the plasma levels of HDL$\mathrm{C}$ and triglycerides nor that some unmeasured factor is responsible for the associations. However, the link between hyperinsulinemia and dyslipidaemia is essentially driven by insulin resistance, NEFA and obesity [42]; a set of variables we have accurately measured and whose contribution, confirmed by multivariate analysis (Figure 1 and 2), was demonstrated to be only partial. In the prospective analysis we did not have a measure of insulin sensitivity at follow-up, but we could rely on BMI and fasting and OGTT plasma glucose, which rather efficiently tracks the changes in insulin resistance in large population samples.

\section{Translational potential}

Hyperinsulinemia and the partial loss of potentiation characterize the earliest derangements of glucose homeostasis in the progression to diabetes and insulin resistance has been considered a key factor in this transition. However, the signal communicating the presence of insulin resistance to the B-cell remains essentially unknown (glucose, NEFA, inflammation, etc) and insulin resistance itself appears to explain only marginally the major changes in insulin secretion. Our data, indicating that plasma HDL-C and triglycerides might contribute to these changes, provide the rationale for designing novel strategies in diabetes prevention, which could be verified in ad hoc designed clinical trials. 


\section{Acknowledgments}

\section{RISC recruiting centres and investigators}

Amsterdam, The Netherlands: RJ Heine, J Dekker, S de Rooij, G Nijpels, W Boorsma Athens, Greece: A Mitrakou, S Tournis, K Kyriakopoulou, P Thomakos

Belgrade, Serbia: N Lalic, K Lalic, A Jotic, L Lukic, M Civcic

Dublin, Ireland: J Nolan, TP Yeow, M Murphy, C DeLong, G Neary, MP Colgan, M Hatunic

Frankfurt, Germany: T Konrad, H Böhles, S Fuellert, F Baer, H Zuchhold

Geneva, Switzerland: A Golay, E Harsch Bobbioni,V. Barthassat, V. Makoundou, TNO Lehmann, T Merminod

Glasgow, Scotland: JR Petrie (now Dundee), C Perry, F Neary, C MacDougall, K Shields, L Malcolm

Kuopio, Finland: M Laakso, U Salmenniemi, A Aura, R Raisanen, U Ruotsalainen, T Sistonen, M Laitinen, H Saloranta

London, England: SW Coppack, N McIntosh, J Ross, L Pettersson, P Khadobaksh

Lyon, France: M Laville, F. Bonnet (now Rennes), A Brac de la Perriere, C LouchePelissier, C Maitrepierre, J Peyrat, S Beltran, A Serusclat

Madrid, Spain: R. Gabriel, EM Sánchez, R. Carraro, A Friera, B. Novella

Malmö, Sweden (1): P Nilsson, M Persson, G Östling, (2): O Melander, P Burri

Milan, Italy: PM Piatti, LD Monti, E Setola, E Galluccio, F Minicucci, A Colleluori

Newcastle-upon-Tyne, England: M Walker, IM Ibrahim, M Jayapaul, D Carman, C Ryan, K Short, Y McGrady, D Richardson

Odense, Denmark: H Beck-Nielsen, P Staehr, K Hojlund, V Vestergaard, C Olsen, L Hansen

Perugia, Italy: GB Bolli, F Porcellati, C Fanelli, P Lucidi, F Calcinaro, A Saturni

Pisa, Italy: E Ferrannini, A Natali, E Muscelli, S Pinnola, M Kozakova, A Casolaro, BD Astiarraga

Rome, Italy: G Mingrone, C Guidone, A Favuzzi, P Di Rocco

Vienna, Austria: C Anderwald, M Bischof, M Promintzer, M Krebs, M Mandl, A Hofer, A Luger, W Waldhäusl, M Roden

\section{Core laboratories and reading centres}

Lipids - Dublin, Ireland: P Gaffney, J Nolan, G Boran

Apolipoprotein - Pisa, Italy, S. Baldi.

Hormones - Odense, Denmark: C Olsen, L Hansen, H Beck-Nielsen

Data Management - Villejuif, France, Padova, and Pisa, Italy: B Balkau, A Mari, L Mhamdi, L Landucci, S Hills, L Mota.

Mathematical modelling and website management - Padova, Italy: A Mari, G Pacini, C Cavaggion, A Tura.

Coordinating office - Pisa, Italy: SA Hills, L Landucci, L Mota.

Project Management Board - B Balkau (Villejuif, France), SW Coppack (London, England), JM Dekker (Amsterdam, The Netherlands), E Ferrannini (Pisa, Italy), A Mari (Padova, Italy), A Natali (Pisa, Italy), M Walker (Newcastle, England).

Further information on the RISC Study and participating centres can be found on www.egir.org.Declaration of interest

None of the author have potential conflicts of interests to disclose with regard to the content of this manuscript. 


\section{Funding}

The RISC Study was supported by EU grant QLG1-CT-2001-01252.

Additional support has been provided by AstraZeneca (Sweden).

The EGIR group activities are supported by an unrestricted research grant from Merck Serono, France.

\section{Disclosure statement}

None of the authors has potential conflict of interests related to the content of the manuscript.

\section{Contribution statement}

A.N.: Study design, data analysis, manuscript writing.

S.B.: Apolipoproteins measurement, data collection and analysis, manuscript revision. F.B.: subject recruitment, clinical investigations, data collection and critical manuscript revision.

J.P.: subject recruitment, clinical investigations, data collection and critical manuscript revision.

D.T.: Data interpretation, review of the literature.

S.T.: subject recruitment, clinical investigations, data collection and data analysis.

A.M.: insulin secretion modelling, critical manuscript revision. 


\section{References}

[1] Wagenknecht LE, Langefeld CD, Scherzinger AL, Norris JM, Haffner SM, Saad MF, et al. Insulin sensitivity, insulin secretion, and abdominal fat: the Insulin Resistance Atherosclerosis Study (IRAS) Family Study. Diabetes. 2003;52:2490-6.

[2] Ferrannini E, Balkau B, Coppack SW, Dekker JM, Mari A, Nolan J, et al. Insulin resistance, insulin response, and obesity as indicators of metabolic risk. Journal of Clinical Endocrinology and Metabolism. 2007;92:2885-92.

[3] Kruit JK, Brunham LR, Verchere CB, Hayden MR. HDL and LDL cholesterol significantly influence beta-cell function in type 2 diabetes mellitus. Curr Opin Lipidol. 2010;21:178-85.

[4] Lee CC, Lorenzo C, Haffner SM, Wagenknecht LE, Goodarzi MO, Stefanovski D, et al. Components of metabolic syndrome and 5-year change in insulin clearance - the Insulin Resistance Atherosclerosis Study. Diabetes, obesity \& metabolism. 2013;15:441-7.

[5] Fryirs MA, Barter PJ, Appavoo M, Tuch BE, Tabet F, Heather AK, et al. Effects of highdensity lipoproteins on pancreatic beta-cell insulin secretion. Arterioscler Thromb Vasc Biol. 2010;30:1642-8.

[6] Abderrahmani A, Niederhauser G, Favre D, Abdelli S, Ferdaoussi M, Yang JY, et al. Human high-density lipoprotein particles prevent activation of the JNK pathway induced by human oxidised low-density lipoprotein particles in pancreatic beta cells. Diabetologia. 2007;50:1304-14.

[7] Drew BG, Duffy SJ, Formosa MF, Natoli AK, Henstridge DC, Penfold SA, et al. Highdensity lipoprotein modulates glucose metabolism in patients with type 2 diabetes mellitus. Circulation. 2009;119:2103-11.

[8] Barter PJ, Rye KA, Tardif JC, Waters DD, Boekholdt SM, Breazna A, et al. Effect of torcetrapib on glucose, insulin, and hemoglobin A1c in subjects in the Investigation of Lipid 
Level Management to Understand its Impact in Atherosclerotic Events (ILLUMINATE) trial. Circulation. 2011;124:555-62.

[9] Fall T, Xie W, Poon W, Yaghootkar H, Magi R, Consortium G, et al. Using Genetic Variants to Assess the Relationship Between Circulating Lipids and Type 2 Diabetes. Diabetes. 2015;64:2676-84.

[10] Jiao J, Dou L, Li M, Lu Y, Guo HB, Man Y, et al. NADPH oxidase 2 plays a critical role in dysfunction and apoptosis of pancreatic beta-cells induced by very low-density lipoprotein. Mol Cell Biochem. 2012;370:103-13.

[11] Lai E, Pettersson U, Verdugo AD, Carlsson PO, Bodin B, Kallskog O, et al. Blood lipids affect rat islet blood flow regulation through beta(3)-adrenoceptors. Am J Physiol Endocrinol Metab. 2014;307:E653-63.

[12] Elks ML. Chronic perifusion of rat islets with palmitate suppresses glucose-stimulated insulin release. Endocrinology. 1993;133:208-14.

[13] Stein DT, Esser V, Stevenson BE, Lane KE, Whiteside JH, Daniels MB, et al.

Essentiality of circulating fatty acids for glucose-stimulated insulin secretion in the fasted rat. J Clin Invest. 1996;97:2728-35.

[14] Sako Y, Grill VE. A 48-hour lipid infusion in the rat time-dependently inhibits glucoseinduced insulin secretion and B cell oxidation through a process likely coupled to fatty acid oxidation. Endocrinology. 1990;127:1580-9.

[15] Mason TM, Goh T, Tchipashvili V, Sandhu H, Gupta N, Lewis GF, et al. Prolonged elevation of plasma free fatty acids desensitizes the insulin secretory response to glucose in vivo in rats. Diabetes. 1999;48:524-30.

[16] Rebelos E, Seghieri M, Natali A, Balkau B, Golay A, Piatti PM, et al. Influence of endogenous NEFA on beta cell function in humans. Diabetologia. 2015;58:2344-52. 
[17] Carpentier A, Mittelman SD, Bergman RN, Giacca A, Lewis GF. Prolonged elevation of plasma free fatty acids impairs pancreatic beta-cell function in obese nondiabetic humans but not in individuals with type 2 diabetes. Diabetes. 2000;49:399-408.

[18] Kashyap S, Belfort R, Gastaldelli A, Pratipanawatr T, Berria R, Pratipanawatr W, et al. A sustained increase in plasma free fatty acids impairs insulin secretion in nondiabetic subjects genetically predisposed to develop type 2 diabetes. Diabetes. 2003;52:2461-74. [19] Manco M, Bertuzzi A, Salinari S, Scarfone A, Calvani M, Greco AV, et al. The ingestion of saturated fatty acid triacylglycerols acutely affects insulin secretion and insulin sensitivity in human subjects. The British journal of nutrition. 2004;92:895-903.

[20] Pivovarova O, Bernigau W, Bobbert T, Isken F, Mohlig M, Spranger J, et al. Hepatic insulin clearance is closely related to metabolic syndrome components. Diabetes Care. 2013;36:3779-85.

[21] Kotronen A, Vehkavaara S, Seppala-Lindroos A, Bergholm R, Yki-Jarvinen H. Effect of liver fat on insulin clearance. American journal of physiology Endocrinology and metabolism. 2007;293:E1709-15.

[22] Hao M, Head WS, Gunawardana SC, Hasty AH, Piston DW. Direct effect of cholesterol on insulin secretion: a novel mechanism for pancreatic beta-cell dysfunction. Diabetes. 2007;56:2328-38.

[23] Sattar N, Preiss D, Murray HM, Welsh P, Buckley BM, de Craen AJ, et al. Statins and risk of incident diabetes: a collaborative meta-analysis of randomised statin trials. Lancet. 2010;375:735-42.

[24] Cederberg H, Stancakova A, Yaluri N, Modi S, Kuusisto J, Laakso M. Increased risk of diabetes with statin treatment is associated with impaired insulin sensitivity and insulin secretion: a 6 year follow-up study of the METSIM cohort. Diabetologia. 2015;58:1109-17. 
[25] Hills SA, Balkau B, Coppack SW, Dekker JM, Mari A, Natali A, et al. The EGIR-RISC Study (the European group for the study of insulin resistance: Relationship between insulin sensitivity and cardiovascular disease risk): I. Methodology and Objectives. Diabetologia. 2004;47:566-70.

[26] Mari A, Schmitz O, Gastaldelli A, Oestergaard T, Nyholm B, Ferrannini E. Meal and oral glucose tests for the assessment of $\beta$-cell function: modeling analysis in normal subjects. Am J Physiol Endocrinol Metab. 2002;283:E1159-66.

[27] Van Cauter E, Mestrez F, Sturis J, Polonsky KS. Estimation of insulin secretion rates from C-peptide levels. Comparison of individual and standard kinetic parameters for Cpeptide clearance. Diabetes. 1992;41:368-77.

[28] Brunham LR, Kruit JK, Pape TD, Timmins JM, Reuwer AQ, Vasanji Z, et al. Beta-cell ABCA1 influences insulin secretion, glucose homeostasis and response to thiazolidinedione treatment. Nature medicine. 2007;13:340-7.

[29] Kruit JK, Kremer PH, Dai L, Tang R, Ruddle P, de Haan W, et al. Cholesterol efflux via ATP-binding cassette transporter A1 (ABCA1) and cholesterol uptake via the LDL receptor influences cholesterol-induced impairment of beta cell function in mice.

Diabetologia. 2010;53:1110-9.

[30] Besseling J, Kastelein JJ, Defesche JC, Hutten BA, Hovingh GK. Association between familial hypercholesterolemia and prevalence of type 2 diabetes mellitus. JAMA. 2015;313:1029-36.

[31] Sharif A, Ravindran V, Moore R, Dunseath G, Luzio S, Owens D, et al. The effect of rosuvastatin on insulin sensitivity and pancreatic beta-cell function in nondiabetic renal transplant recipients. American journal of transplantation : official journal of the American Society of Transplantation and the American Society of Transplant Surgeons. 2009;9:143945. 
[32] Paniagua JA, Lopez-Miranda J, Escribano A, Berral FJ, Marin C, Bravo D, et al.

Cerivastatin improves insulin sensitivity and insulin secretion in early-state obese type 2 diabetes. Diabetes. 2002;51:2596-603.

[33] Yaluri N, Modi S, Lopez Rodriguez M, Stancakova A, Kuusisto J, Kokkola T, et al. Simvastatin Impairs Insulin Secretion by Multiple Mechanisms in MIN6 Cells. PLoS One. 2015;10:e0142902.

[34] Mari A, Gastaldelli A, Natali A, Ostergard T, Schmitz O, Ferrannini E. Characterization of $\beta$-cell function impairment in first-degree relatives of type 2 diabetic subjects: Modeling analysis of 24-h triple-meal tests. American Journal of Physiology - Endocrinology and Metabolism. 2005;288.

[35] Siebel AL, Natoli AK, Yap FY, Carey AL, Reddy-Luthmoodoo M, Sviridov D, et al. Effects of high-density lipoprotein elevation with cholesteryl ester transfer protein inhibition on insulin secretion. Circ Res. 2013;113:167-75.

[36] Rickels MR, Goeser ES, Fuller C, Lord C, Bowler AM, Doliba NM, et al. Loss-offunction mutations in ABCA1 and enhanced beta-cell secretory capacity in young adults. Diabetes. 2015;64:193-9.

[37] Briscoe CP, Tadayyon M, Andrews JL, Benson WG, Chambers JK, Eilert MM, et al. The orphan G protein-coupled receptor GPR40 is activated by medium and long chain fatty acids. J Biol Chem. 2003;278:11303-11.

[38] Fizelova M, Miilunpohja M, Kangas AJ, Soininen P, Kuusisto J, Ala-Korpela M, et al. Associations of multiple lipoprotein and apolipoprotein measures with worsening of glycemia and incident type 2 diabetes in 6607 non-diabetic Finnish men. Atherosclerosis. 2015;240:272-7. 
[39] Tenenbaum A, Motro M, Fisman EZ, Schwammenthal E, Adler Y, Goldenberg I, et al. Peroxisome proliferator-activated receptor ligand bezafibrate for prevention of type 2 diabetes mellitus in patients with coronary artery disease. Circulation. 2004;109:2197-202. [40] Tenenbaum H, Behar S, Boyko V, Adler Y, Fisman EZ, Tanne D, et al. Long-term effect of bezafibrate on pancreatic beta-cell function and insulin resistance in patients with diabetes. Atherosclerosis. 2007;194:265-71.

[41] Kang ZF, Deng Y, Zhou Y, Fan RR, Chan JC, Laybutt DR, et al. Pharmacological reduction of NEFA restores the efficacy of incretin-based therapies through GLP-1 receptor signalling in the beta cell in mouse models of diabetes. Diabetologia. 2013;56:423-33. [42] Adiels M, Olofsson SO, Taskinen MR, Boren J. Diabetic dyslipidaemia. Current opinion in lipidology. 2006;17:238-46. 


\section{Figure legends}

Figure 1 - Mean values of fasting (upper panels) and OGTT (lower panels) plasma insulin concentrations are displayed according to gender-specific quartiles of serum LDL-C, HDL-C and triglycerides in 1,017 non-diabetic subjects. Filled symbols/continuous lines are mean (SD) for each pair of variables. Empty symbols/dotted lines are quartiles least square means and SEM resulting from ANCOVA with gender, BMI, age, M/I and either fasting or OGTT plasma glucose concentration as independent variables. $p$ values refer to either ANOVA or ANCOVA F-test.

Figure 2 - Bar graph of simple means $( \pm 95 \% \mathrm{CI}$, white bars) and least square means $( \pm \mathrm{SEM}$, gray and black bars) of fasting ( $a$ and $b$ ) and OGTT (d and e) insulin secretion rates. Light gray bars represent least square means that are adjsted for age, gender, BMI and M/I; black bars are further adjusted for the other two cognate components of the lipid profile. Bar graph of the mean values of fasting (c) and OGTT (f) insulin secretion rates according to triglycerides and HDL quartiles.

Figure 3 - Mean values $( \pm 95 \mathrm{CI})$ of the insulin secretion rate at a plasma glucose concentration of $5.0 \mathrm{mM}$ (ISR@5) and of the potentiation factor ratio (PFR) across quartiles of either HDL-C (black circles) and triglycerides (white circles) plotted against the corresponding mean values $( \pm \mathrm{SD})$ of plasma HDL-C and triglycerides of each quartile. $p$ value refers to two-way ANOVA F-test statistics.

Figure 4 - Plot of the mean changes $( \pm$ SEM) in fasting insulin secretion rates according to the mean changes $( \pm$ SEM) in both HDL-C and triglycerides grouped according to quartiles of either lipid changes observed over 3.5 years. Full lines connect the crude mean values, the dotted lines connect the mean values adjusted for change in BMI, and in fasting plasma glucose. 

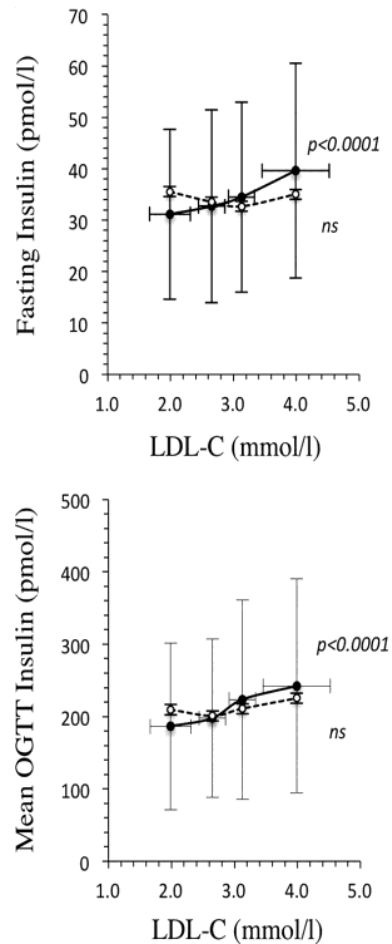

LDL-C (mmol/l)

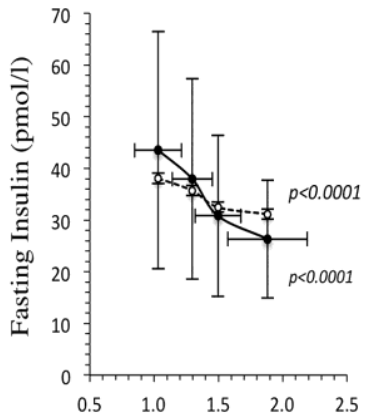

HDL-C (mmol/l)

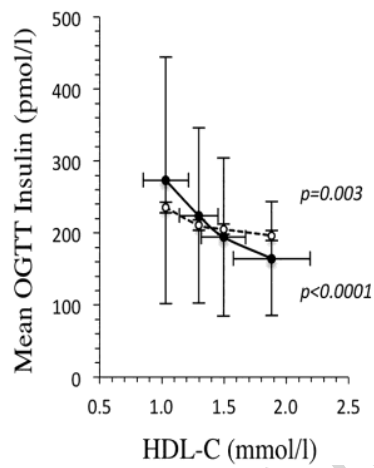

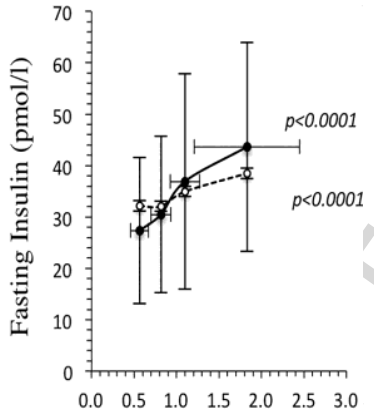

Triglycerides (mmol/l)

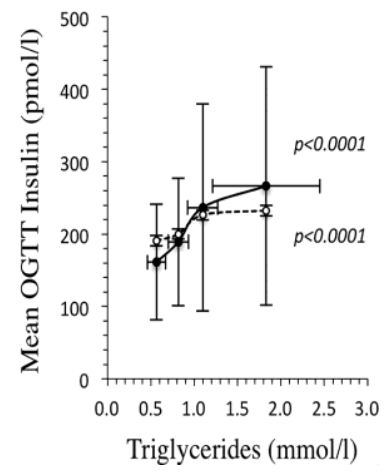

Fig. 1 

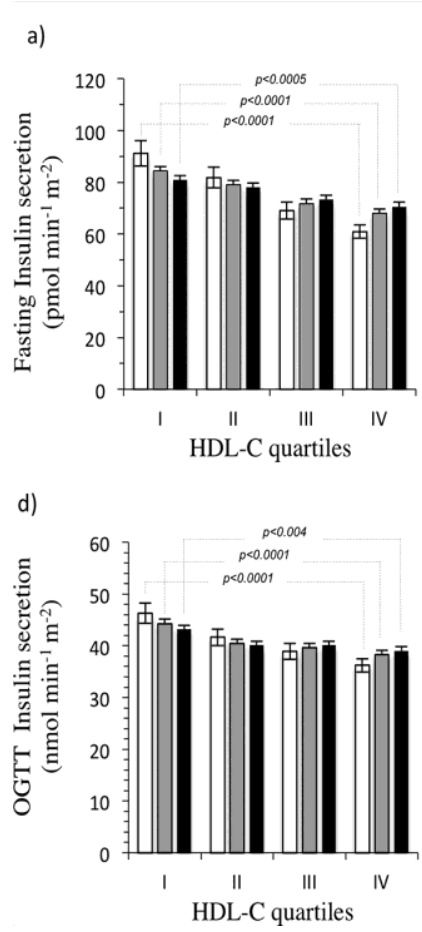

Fig. 2 b)

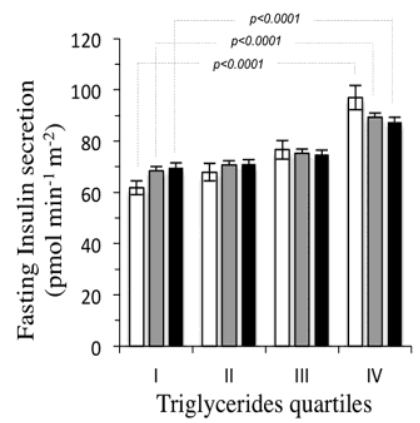

e)

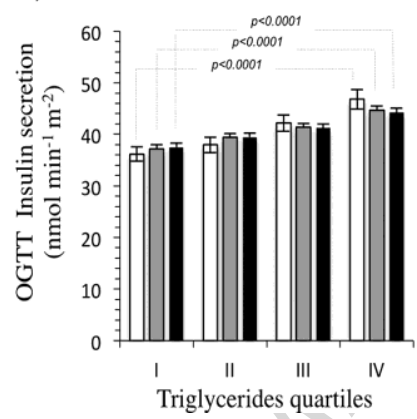

c)

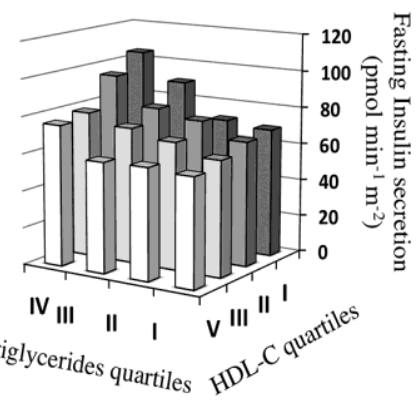

f)

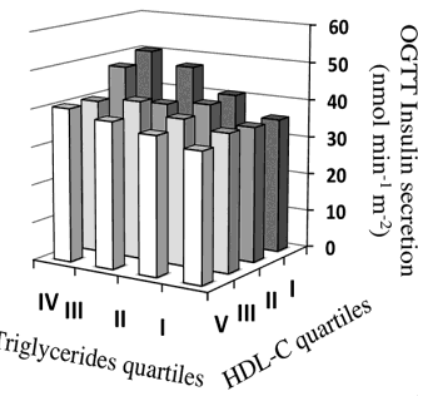




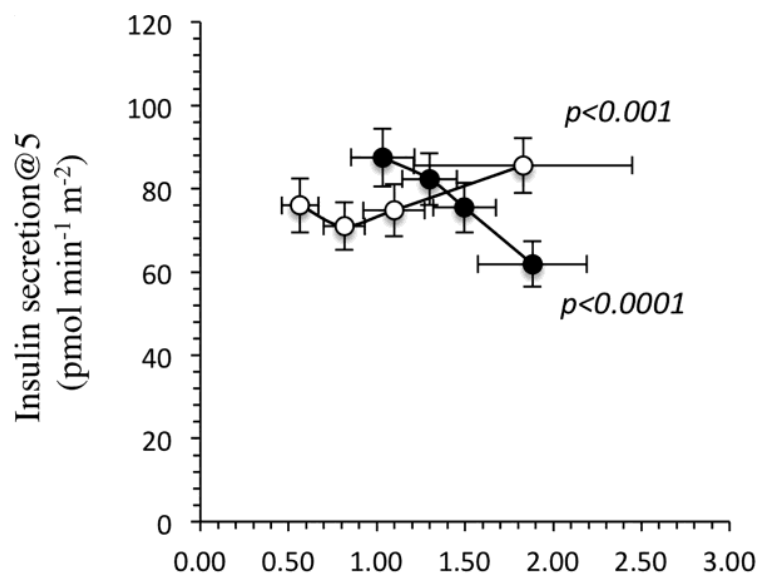

HDL-C or Triglycerides (mmol/l)

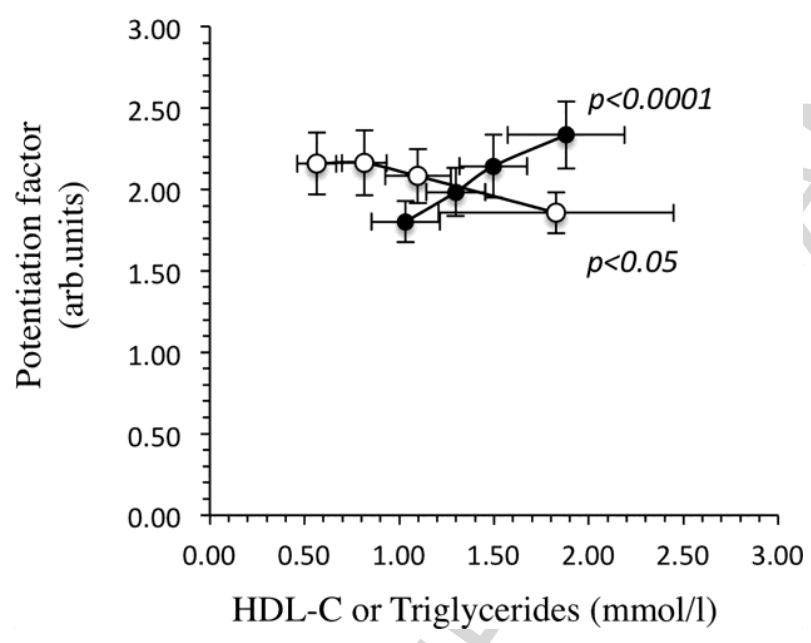

Fig. 3 


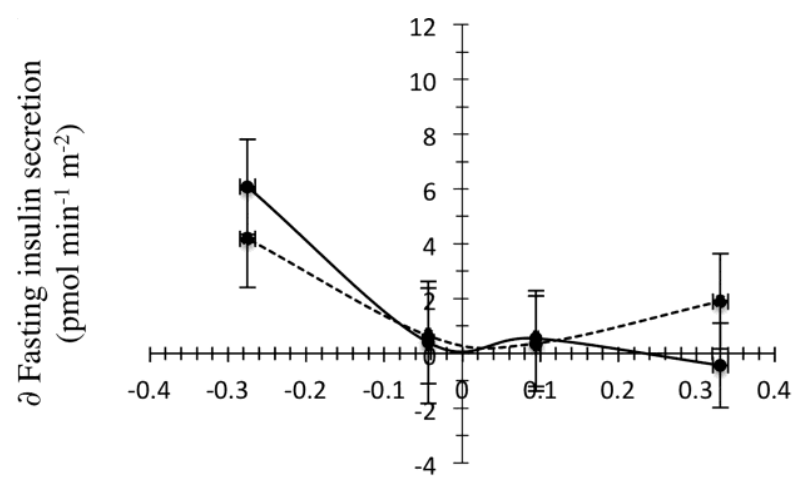

ว HDL-C (mmol/l)

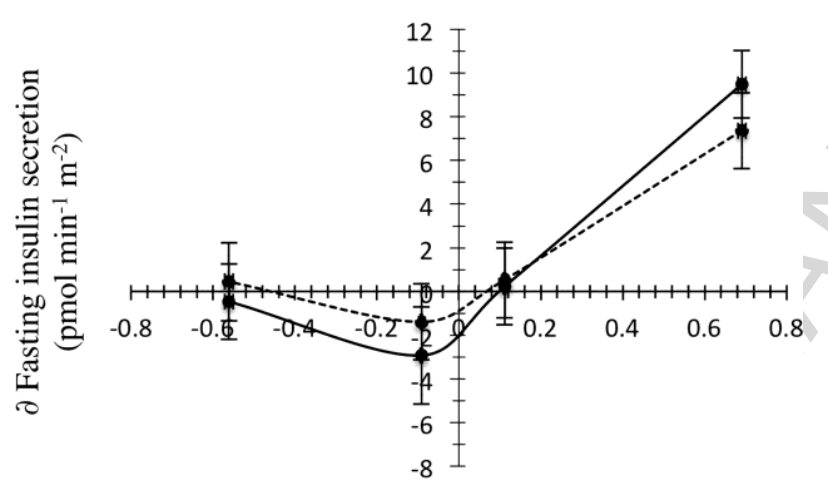

$\partial$ Triglycerides (mmol/l)

Fig. 4 
Table 1 - Anthropometric and metabolic characteristics of study subjects

\begin{tabular}{|c|c|c|c|c|c|}
\hline & \multicolumn{2}{|c|}{ Women $(n=556)$} & \multicolumn{2}{|c|}{$\operatorname{Men}(n=461)$} & \multirow[b]{2}{*}{$p$ value } \\
\hline & mean \pm SD & [Range] & mean $\pm \mathrm{SD}$ & [Range] & \\
\hline Age (years) & $45 \pm 8$ & {$[30-61]$} & $44 \pm 9$ & {$[30-60]$} & 0.0460 \\
\hline Waist $(\mathrm{cm})$ & $81 \pm 11$ & {$[49-121]$} & $93 \pm 10$ & {$[69-123]$} & $<0.0001$ \\
\hline BMI $\left(\mathrm{Kg} / \mathrm{m}^{2}\right)$ & $24.7 \pm 4.1$ & {$[16.9-40.0]$} & $26.1 \pm 3.4$ & {$[17.0-40.0]$} & $<0.0001$ \\
\hline Systolic blood pressure (mmHg) & $114 \pm 13$ & [79-140] & $122 \pm 11$ & [92-140] & $<0.0001$ \\
\hline Diastolic blood pressure (mmHg) & $73 \pm 7$ & [50-90] & $76 \pm 6$ & [53-90] & $<0.0001$ \\
\hline Fasting plasma glucose $(\mathrm{mmol} / \mathrm{l})$ & $4.98 \pm 0.54$ & [2.9-7.0] & $5.2 \pm 0.51$ & [3.1-7.0] & $<0.0001$ \\
\hline Fasting plasma insulin $(\mathrm{pmol} / \mathrm{l})$ & $34 \pm 19$ & {$[7-117]$} & $36 \pm 19$ & [6-137] & 0.0784 \\
\hline Fasting plasma glucagon $(\mathrm{pmol} / \mathrm{l})$ & $8.1 \pm 3.4$ & [2-26] & $10.0 \pm 4.5$ & [2-28] & $<0.0001$ \\
\hline 2h Plasma glucose $(\mathrm{mmol} / \mathrm{l})$ & $5.85 \pm 1.56$ & {$[2.2-11.0]$} & $5.64 \pm 1.47$ & {$[2.2-11.0]$} & 0.0425 \\
\hline $\mathbf{M} / \mathbf{I}\left(\mu \mathrm{mol} \min ^{-1} \mathrm{~kg}_{\mathrm{FFM}}{ }^{-1} \mathrm{pM}^{-1}\right)$ & $156 \pm 66$ & {$[22-476]$} & $126 \pm 65$ & {$[12-454]$} & $<0.0001$ \\
\hline Total Cholesterol (mmol/l) & $4.83 \pm 0.87$ & {$[2.80-7.90]$} & $4.92 \pm 0.96$ & {$[2.70-8.20]$} & 0.0651 \\
\hline LDL Cholesterol (mmol/l) & $2.82 \pm 0.81$ & {$[0.81-6.12]$} & $3.10 \pm 0.77$ & {$[1.52-5.56]$} & $<0.0001$ \\
\hline HDL Cholesterol (mmol/l) & $1.56 \pm 0.38$ & {$[0.52-2.88]$} & $1.25 \pm 0.30$ & {$[0.52-2.26]$} & $<0.0001$ \\
\hline Triglycerides (mmol/l) & $0.94 \pm 0.44$ & {$[0.33-3.02]$} & $1.24 \pm 0.67$ & {$[0.32-3.85]$} & $<0.0001$ \\
\hline $\operatorname{ApoA1}(\mathrm{mg} / \mathrm{dl})$ & $139 \pm 28$ & [73-240] & $126 \pm 23$ & [73-210] & $<0.0001$ \\
\hline $\operatorname{ApoA2}(\mathrm{mg} / \mathrm{dl})$ & $33 \pm 11$ & [15-79] & $34 \pm 10$ & {$[15-71]$} & 0.3265 \\
\hline ApoB (mg/dl) & $123 \pm 50$ & [31-340] & $138 \pm 57$ & [35-352] & $<0.0001$ \\
\hline ApoC3 (mg/dl) & $17 \pm 7$ & [2-46] & $19 \pm 9$ & [2-67] & 0.0067 \\
\hline $\operatorname{ApoE}(\mathrm{mg} / \mathrm{dl})$ & $5 \pm 9$ & {$[1-14]$} & $5 \pm 2$ & [1-18] & 0.2124 \\
\hline
\end{tabular}


Table 2 - Univariate associations between serum lipids/apoliporoteins and parameters affecting plasma insulin concentration ${ }^{\circ}$

\begin{tabular}{|c|c|c|c|c|c|c|c|c|c|c|c|c|}
\hline & \multicolumn{3}{|c|}{ ISR fast } & \multicolumn{3}{|c|}{ ISR ogtt } & \multicolumn{3}{|c|}{ IC fast } & \multicolumn{3}{|c|}{ IC ogtt } \\
\hline & All & $\begin{array}{c}\text { Wom } \\
\text { en }\end{array}$ & $\begin{array}{c}\mathrm{Me} \\
\mathrm{n}\end{array}$ & All & $\begin{array}{c}\text { Wom } \\
\text { en }\end{array}$ & $\begin{array}{c}\mathrm{Me} \\
\mathrm{n}\end{array}$ & All & $\begin{array}{c}\text { Wom } \\
\text { en }\end{array}$ & $\begin{array}{c}\mathrm{Me} \\
\mathrm{n}\end{array}$ & All & $\begin{array}{c}\text { Wom } \\
\text { en }\end{array}$ & $\begin{array}{c}\mathrm{Me} \\
\mathrm{n}\end{array}$ \\
\hline $\begin{array}{l}\text { Total } \\
\text { Cholester } \\
\text { ol } \\
(\mathrm{mmol} / \mathrm{l})\end{array}$ & $\begin{array}{c}0.13 \\
9\end{array}$ & 0.060 & $\begin{array}{c}0.22 \\
2\end{array}$ & $\begin{array}{c}0.10 \\
3\end{array}$ & 0.023 & $\begin{array}{c}0.19 \\
6\end{array}$ & $\begin{array}{c}0.05 \\
3\end{array}$ & & 0.05 & $\begin{array}{c}0.10 \\
5\end{array}$ & 0.066 & $\begin{array}{c}- \\
0.14 \\
7\end{array}$ \\
\hline $\begin{array}{l}\text { HDL } \\
\text { Cholester } \\
\text { ol } \\
(\mathrm{mmol} / \mathrm{l})\end{array}$ & $\begin{array}{c}-\overline{39} \\
5\end{array}$ & 0.377 & $\begin{array}{c}- \\
0.41 \\
0\end{array}$ & $\begin{array}{c}\overline{0.25} \\
2\end{array}$ & $0 . \overline{254}$ & $\begin{array}{c}- \\
0.31 \\
4\end{array}$ & 0.13 & 0.165 & $\begin{array}{c}0.10 \\
4\end{array}$ & $\begin{array}{c}0.20 \\
3\end{array}$ & 0.198 & $\begin{array}{c}0.26 \\
2\end{array}$ \\
\hline $\begin{array}{l}\text { LDL } \\
\text { Cholester } \\
\text { ol } \\
(\mathrm{mmol} / \mathrm{l})\end{array}$ & $\begin{array}{c}0.19 \\
4\end{array}$ & 0.154 & $\begin{array}{c}0.21 \\
4\end{array}$ & $\begin{array}{c}0.13 \\
4\end{array}$ & 0.084 & $\begin{array}{c}0.20 \\
4\end{array}$ & $\begin{array}{c}0.08 \\
6\end{array}$ & 0.079 & $\begin{array}{c}- \\
0.08 \\
2\end{array}$ & $\begin{array}{c}0.15 \\
1\end{array}$ & $0 . \overline{125}$ & $\begin{array}{c}- \\
0.17 \\
8\end{array}$ \\
\hline $\begin{array}{l}\text { Triglyceri } \\
\text { des } \\
(\mathrm{mmol} / \mathrm{l})\end{array}$ & $\begin{array}{c}0.41 \\
7\end{array}$ & 0.334 & $\begin{array}{c}0.49 \\
1\end{array}$ & $\begin{array}{c}0.29 \\
9\end{array}$ & 0.242 & $\begin{array}{c}0.39 \\
2\end{array}$ & $\begin{array}{c}- \\
0.11 \\
7\end{array}$ & $\dot{-}$ & $\begin{array}{c}- \\
0.09 \\
1\end{array}$ & $\begin{array}{c}- \\
0.20 \\
2\end{array}$ & $\begin{array}{c}- \\
0.172\end{array}$ & $\begin{array}{c}- \\
0.28 \\
5\end{array}$ \\
\hline $\begin{array}{l}\text { Apo B } \\
(\mathrm{mg} / \mathrm{dl})\end{array}$ & $\begin{array}{c}0.27 \\
8\end{array}$ & 0.191 & $\begin{array}{c}0.35 \\
3\end{array}$ & 0.1 & 0.113 & $\begin{array}{c}0.26 \\
3\end{array}$ & $\begin{array}{c}- \\
0.05 \\
9\end{array}$ & $\overline{-}-\overline{041}$ & $\begin{array}{c}- \\
0.07 \\
5\end{array}$ & $\begin{array}{c}- \\
0.11 \\
1\end{array}$ & 0.074 & $\begin{array}{c}- \\
0.15 \\
6\end{array}$ \\
\hline $\begin{array}{l}\text { Apo A1 } \\
(\mathrm{mg} / \mathrm{dl})\end{array}$ & $\begin{array}{c}- \\
0.07 \\
4\end{array}$ & - & $\begin{array}{c}- \\
0.05 \\
9\end{array}$ & $\begin{array}{c}0.04 \\
0\end{array}$ & 0.047 & $\begin{array}{c}- \\
0.03 \\
0\end{array}$ & $\begin{array}{c}0.03 \\
0\end{array}$ & 0.014 & $\begin{array}{c}0.05 \\
2\end{array}$ & $\begin{array}{c}0.03 \\
0\end{array}$ & 0.019 & $\begin{array}{c}0.09 \\
2\end{array}$ \\
\hline $\begin{array}{l}\text { Apo E } \\
(\mathrm{mg} / \mathrm{dl})\end{array}$ & $\begin{array}{c}0.22 \\
8\end{array}$ & & $\begin{array}{c}0.30 \\
5\end{array}$ & $\begin{array}{c}0.17 \\
8\end{array}$ & 0.080 & $\begin{array}{c}0.28 \\
5\end{array}$ & $\begin{array}{c}- \\
0.08 \\
3\end{array}$ & $0 . \overline{084}$ & $\begin{array}{c}- \\
0.07 \\
7\end{array}$ & $\begin{array}{c}- \\
0.11 \\
0\end{array}$ & 0.038 & $\begin{array}{c}- \\
0.19 \\
3\end{array}$ \\
\hline $\begin{array}{l}\text { Apo CIII } \\
(\mathrm{mg} / \mathrm{dl})\end{array}$ & $\begin{array}{c}0.20 \\
6\end{array}$ & & $\begin{array}{c}0.28 \\
7\end{array}$ & $\begin{array}{c}0.12 \\
9\end{array}$ & 0.071 & $\begin{array}{c}0.19 \\
2\end{array}$ & $\begin{array}{c}0.01 \\
8\end{array}$ & 0.023 & $\begin{array}{c}0.01 \\
5\end{array}$ & $\begin{array}{c}0.02 \\
7\end{array}$ & 0.055 & $\begin{array}{c}- \\
0.00 \\
3\end{array}$ \\
\hline $\begin{array}{l}\text { Apo A2 } \\
(\mathrm{mg} / \mathrm{dl})\end{array}$ & $\begin{array}{c}0.04 \\
0\end{array}$ & 0.037 & $\begin{array}{c}0.11 \\
4\end{array}$ & $\begin{array}{c}0.05 \\
2\end{array}$ & 0.009 & $\begin{array}{c}0.10 \\
1\end{array}$ & $\begin{array}{c}- \\
0.04 \\
0\end{array}$ & $0 . \overline{042}$ & $\begin{array}{c}- \\
0.04 \\
1\end{array}$ & $\begin{array}{c}- \\
0.05 \\
7\end{array}$ & $\begin{array}{c}- \\
0.054\end{array}$ & $\begin{array}{c}- \\
0.05 \\
8\end{array}$ \\
\hline $\begin{array}{l}\text { ApoA1/H } \\
\text { DL }\end{array}$ & $\begin{array}{c}0.34 \\
9\end{array}$ & 0.310 & $\begin{array}{c}0.37 \\
3\end{array}$ & $\begin{array}{c}0.23 \\
7\end{array}$ & 0.204 & $\begin{array}{c}0.30 \\
5\end{array}$ & $\begin{array}{c}- \\
0.09 \\
1\end{array}$ & $\begin{array}{c}- \\
0.113\end{array}$ & $\begin{array}{c}- \\
0.06 \\
9\end{array}$ & $\begin{array}{c}- \\
0.16 \\
2\end{array}$ & $\begin{array}{c}- \\
0.157\end{array}$ & $\begin{array}{c}- \\
0.19 \\
3\end{array}$ \\
\hline $\begin{array}{l}\text { ApoB/LD } \\
\text { L }\end{array}$ & $\begin{array}{c}0.16 \\
3\end{array}$ & 0.076 & $\begin{array}{c}0.26 \\
5\end{array}$ & $\begin{array}{c}0.11 \\
6\end{array}$ & 0.009 & $\begin{array}{c}0.17 \\
2\end{array}$ & $\begin{array}{c}0.00 \\
2\end{array}$ & 0.034 & $\begin{array}{c}0.03 \\
7\end{array}$ & $\begin{array}{c}- \\
0.00 \\
9\end{array}$ & 0.036 & $\begin{array}{c}- \\
0.06 \\
3 \\
\end{array}$ \\
\hline
\end{tabular}

- Speraman correleation coeficient for fasting and OGTT insulin secretion rates (ISR fast and ISR ogtt, respectively) and for fasting and OGTT insulin clearance (IC fast and IC ogtt, respectively). Units are ISR fast: pmol $\mathrm{min}^{-1} \mathrm{~m}^{-2}$; ISR ogtt: $\mathrm{nmol} / \mathrm{m}^{2}$; IC fast and IC ogtt: $1 \mathrm{~min}^{-1} \mathrm{~m}^{-2}$.

For All: ro $>0.061, p<0.05 ;$ ro $>0.083, p<0.01 ;$ ro $>0.105, p<0.001$; for women and men ro $>0.089$, $\mathrm{p}<0.05$, ro $>0.110, \mathrm{p}<0.01 ; \mathrm{ro}>0.140, \mathrm{p}<0.001$ 
Table 3 - Mutivariate regression $(n=978)^{\circ}$

\begin{tabular}{|c|c|c|c|c|c|c|}
\hline & \multicolumn{3}{|c|}{ ISR fast } & \multicolumn{3}{|c|}{ ISR ogtt } \\
\hline & St.B & $p$ value & VIF & St. $\beta$ & $p$ value & VIF \\
\hline Gender (Female) & 0.14 & $<0.0001$ & 1.32 & 0.19 & $<0.0001$ & 1.27 \\
\hline Age (yrs) & -0.06 & 0.0217 & & 0.01 & 0.6959 & 1.23 \\
\hline BMI $\left(\mathrm{kg} / \mathrm{m}^{2}\right)$ & 0.27 & $<0.0001$ & & 0.01 & 0.6574 & 1.40 \\
\hline Plasma Glucose* $(\mathrm{mmol} / \mathrm{l})$ & 0.25 & $<0.0001$ & & -0.33 & $<0.0001$ & 1.39 \\
\hline $\mathbf{M} / \mathbf{I}\left(\mu \mathrm{mol} \min ^{-1} \mathrm{~kg}_{\mathrm{FFM}}{ }^{-1} \mathrm{pM}^{-1}\right)$ & -0.21 & 0.00 & 1.48 & -0.26 & $<0.0001$ & 1.53 \\
\hline LDL cholesterol (mmol/1) & -0.02 & 0.5356 & 1.28 & 0.01 & 0.6937 & 1.27 \\
\hline HDL cholesterol (mmol/l) & -0.10 & $<0.0031$ & 1.70 & -0.10 & 0.0034 & 1.69 \\
\hline Triglycerides (mmol/l) & 0.22 & $<0.0001$ & 1.48 & 0.16 & $<0.0001$ & 1.49 \\
\hline Whole model $\mathbf{R}^{2}$ & 0.44 & $<0.0001$ & & 0.40 & $<0.0001$ & \\
\hline
\end{tabular}

- Each model includes centres as dummy variables, waist was excluded from the model on the bases of a VIF values $\geq 3$ in both models. ISR fast and ogtt $=$ Fasting and OGTT insulin secretion rate (Units: pmol $\mathrm{min}^{-1} \mathrm{~m}^{-2}$ and $\mathrm{nmol} / \mathrm{m}^{2}$, respectively)

* Glucose is fasting glucose and mean OGTT glucose for fasting and OGTT insulin secretion, respectively. 